\title{
HRF-Interacting Molecules
}

\author{
Toshiaki Kawakami*, Tomoaki Ando, and Yuko Kawakami
}

Division of Cell Biology, La Jolla Institute for Allergy and Immunology, La Jolla, California 92037-1387, USA

\begin{abstract}
Histamine-releasing factor (HRF), also termed translationally controlled tumor protein (TCTP) and fortilin, is a highly conserved, multi-functional protein. This protein within a cell plays a critical role in the fundamental processes of cell-cycle progression, proliferation, survival, and malignant transformation. The same protein, despite the lack of signal sequence, is secreted through a nonclassical secretory pathway. The secreted protein usually termed HRF can activate IgE-primed basophils and mast cells, and works as a B cell growth factor and a chemoattractant for eosinophils. This structurally well-characterized protein interacts with many proteins to perform its intracellular and extracellular functions. This review summarizes recent studies of HRF/TCTP-interacting proteins as a major driving force to decipher its functions.
\end{abstract}

Keywords: Allergy, asthma, basophil, HRF, mast cell, proliferation, survival, TCTP.

\section{INTRODUCTION}

The search for interacting molecules is a rewarding effort to decipher the properties of a protein. Identification of the interacting proteins often provides important clues on the localization, trafficking, and function of the protein. Numerous methods have been developed for this purpose, including co-immunoprecipitation, GST (or other protein) fusion pulldown, yeast two-hybrid, and tandem affinity purification [1, 2]. With genomics-based large databases being available, combination of these methods with mass spectrometric identification of peptides is very powerful.

HRF, also termed TCTP, p21, p23, Q23, and fortilin, is a highly conserved, multi-functional protein. This protein within a cell plays a critical role in the fundamental processes of cell-cycle progression, proliferation, survival, and malignant transformation (reviewed by Bommer in this Hot Topic series). Despite the lack of signal sequence, this protein can be secreted. Historically, TCTP has been used as the term for its intracellular function, while HRF has been favored as the term for the secreted protein. TCTP/HRF exhibits amino acid sequence identities of over $40 \%$ between distantly related species $[3,4]$. The 3 -dimensional structures of TCTP from the yeast Schizosaccharomyces pombe [5], the parasite Plasmodium knowlesi [6], and human [7] have been solved (Fig. 1). Fifteen of approximately 170 residues are completely or nearly completely conserved in TCTP proteins from yeast, pea, nematode, fruit fly, and mouse [3]. These invariant residues are largely clustered on one side of the $\beta$ stranded 'core' domain. The fold of this domain is similar to that of the Mss4/Dss4 family of proteins, which bind to the GDP/GTP free form of Rab proteins (members of the Ras superfamily) [5]. A flexible loop (TCTP1) and the C-

*Address correspondence to this author at the Division of Cell Biology, La Jolla Institute for Allergy and Immunology, 9420 Athena Circle La Jolla, California 92037-1387, USA; Tel: (858) 752-6814; Fax: (858) 752-6986; E-mail: toshi@liai.org

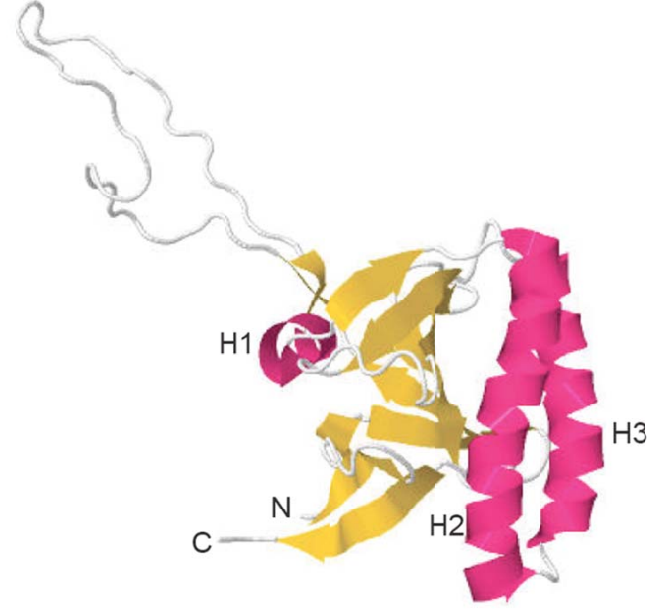

Fig. (1). Three-dimensional structure of human TCTP from as revealed by solution NMR spectroscopy. The $\beta$-stranded 'core' is similar to the fold of Mss4. TCTP-specific $\alpha$-helices H1, H2, and $\mathrm{H} 3$ are shown. Taken from Protein Data Bank (PDB) 2HR.

terminal loop (TCTP2) following the $\alpha$-helices comprise the TCTP signatures. The tubulin-binding region and the $\mathrm{Ca}^{2+}$ binding area were mapped to the helical domain. A structural similarity was identified between the $\mathrm{H} 2-\mathrm{H} 3$ helices of TCTP and the H5-H6 helices of Bax, the part of the molecule implicated in the regulation of mitochondrial membrane permeability during apoptosis [7].

\section{TCTP CONTROLS FUNDAMENTAL PROCESSES OF GROWTH, PROLIFERATION, SURVIVAL, AND MALIGNANT TRANSFORMATION}

The name "translationally controlled tumor protein" was given to this protein, because TCTP mRNA levels were high but the protein was not detected in Ehrlich acites tumor cells $[8,9]$. TCTP is ubiquitously expressed in all tested eukaryotic cells; its expression is active in mitotically active tissues $[10,11]$ and subject to both transcriptional and translational 
Table 1. HRF Binding Partners

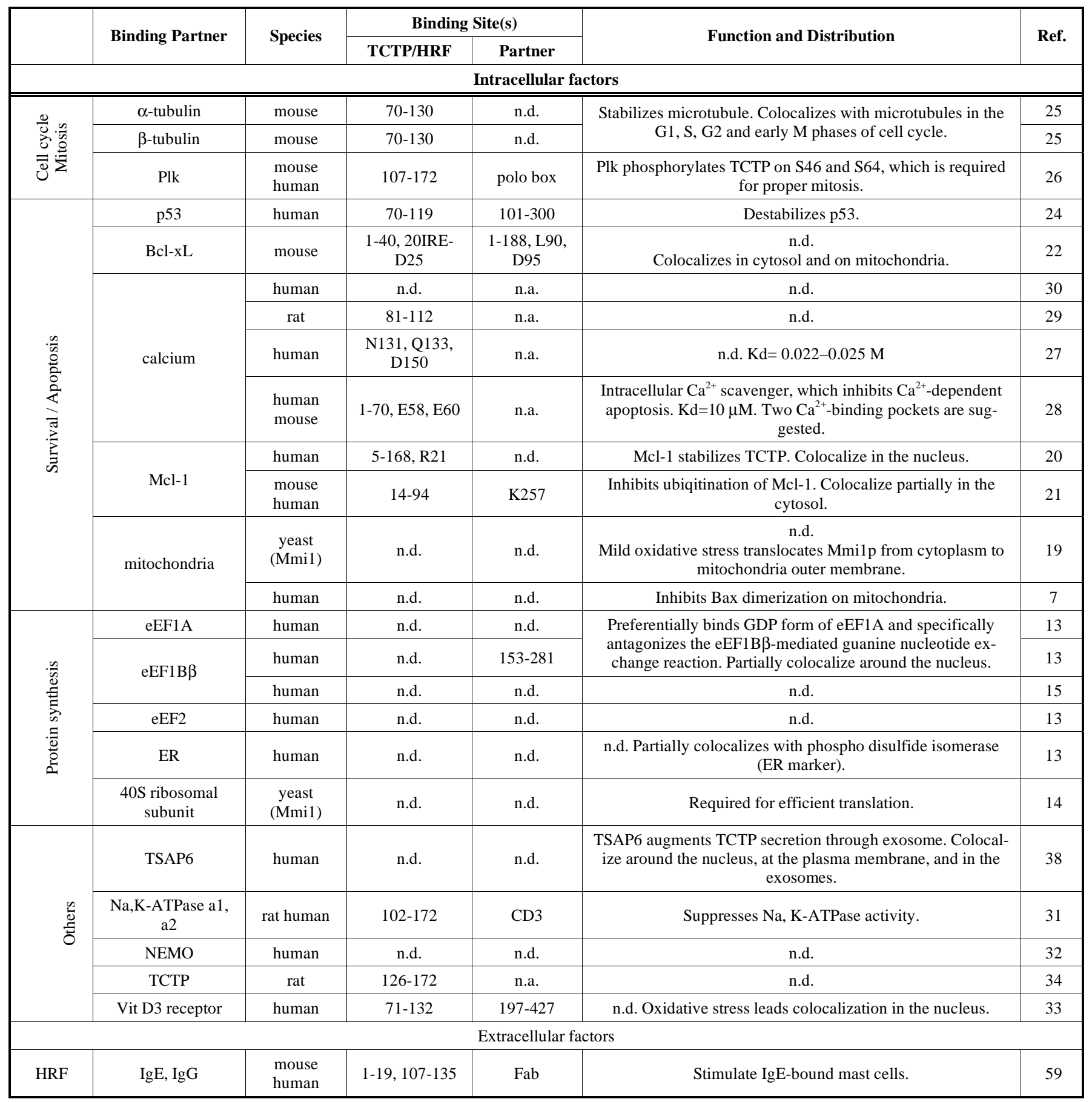

$\mathrm{Ca}^{2+}$ binding (27-30) and dimerization of TCTP (34) are also included in this table. n.d. not determined, n.a. not applicable.

control [12]. It is involved in the elongation step of protein synthesis by interacting with both eEF1A (a small GTPase) and eEF1B $\beta$ (a guanine nucleotide exchange factor) (Table 1) [13-15]. TCTP inhibits the latter activity, thus slowing down the elongation process, avoiding 'skipping', and resulting in more efficient elongation. $G$ protein binding via the 'core' domain seems to be well conserved among most of TCTPs in various species. Indeed, Drosophila TCTP acts as the guanine nucleotide-exchange factor for Rheb (Ras homologue enriched in brain), a Ras superfamily GTPase that regulates the TSC1-TSC2-mTOR pathway [16]. Lowering Drosophila TCTP levels reduces cell size, cell number and organ size, which mimics Drosophila Rheb mutant phenotypes. Conventional TCTP KO mice are embryonic lethal $[17,18]$. These Drosophila and mouse studies strongly implicate this protein in the regulation of growth and proliferation as well as in the control of organ size. Another conserved property of TCTP is its interaction with microtubules and mitochondria [19]. TCTP interacts with 
and mitochondria [19]. TCTP interacts with Mcl-1 [20, 21] and Bcl-xL [22], anti-apoptotic members of the Bcl-2 family. TCTP stabilizes Mcl-1 through interfering with Mcl-1's degradation by the ubiquitin-dependent proteasome degradation pathway [21]. TCTP also antagonizes apoptosis by inserting into the mitochondrial membrane and inhibiting Bax dimerization [7]. RNA interference-mediated knockdown of TCTP increases the frequency of tumor reversion apparently consistent with its anti-apoptotic function [23]. By contrast, yeast TCTP displays proapoptotic activity, apparently via an interaction with the outer mitochondrial membrane [19]. A recent study identified p53 tumor suppressor as another TCTP-interacting protein [24]. Overexpression of TCTP in lung carcinoma cells reversed p53-mediated apoptosis and inhibition of TCTP expression by small interfering RNA increased apoptosis of lung carcinoma cells. Moreover, it was observed that TCTP overexpression promotes degradation of $\mathrm{p} 53$. Thus, TCTP acts as a negative regulator of apoptosis in lung cancer. TCTP interacts with tubulins [25]. Phosphorylation of TCTP by the protein kinase Plk decreases the microtubule-stabilizing activity of TCTP [26]. TCTP is a $\mathrm{Ca}^{2+}$-binding protein [27-30] and other TCTPinteracting proteins include $\mathrm{Na}$, K-ATPases [31], NEMO [32] and vitamin $\mathrm{D}_{3}$ receptor [33] as well as itself [34].

\section{HRF Promotes Allergic Responses}

Since Thueson et al. first described an activity from cultured peripheral blood mononuclear cells that induced the release of histamine from basophils [35], histamine-releasing activities have been studied for more than 30 years [36]. In addition to several cytokines and chemokines with this activity, an unrelated protein termed histamine-releasing factor (HRF) was purified and molecularly cloned in 1995 [37] as the factor that could explain the activity found in nasal lavages, skin blister fluids, and BAL fluids during the late phase of allergic reactions [38-40]. However, it is not known whether the Thueson/Grant molecule and the molecule found in late phase reactions, are the same as this HRF. Sampson et al. showed that patients with food hypersensitivity and atopic dermatitis, but not patients with atopic dermatitis without food hypersensitivity, have higher rates of spontaneous release of histamine from basophils than normal subjects [41]. This histamine-releasing activity declined when patients avoided the offending foods for an extended period. Again, it is not known whether this interesting observation is directly related to HRF.

HRF secretion is insensitive to brefeldin A or monensin, but can be enhanced by TSAP6, a p53-inducible 5-6 transmembrane protein. HRF can be found in exosomes, suggesting that HRF is secreted through a nonclassical exosome pathway [42] (reviewed by Maeng et al. in this Hot Topic). Since human recombinant HRF can stimulate histamine release and cytokine (IL-4 and IL-13) production from IgEsensitized basophils and mast cells [37, 43, 44], it can be considered an IgE-dependent cytokine. MacDonald et al. revealed that cell-bound IgE is required for HRF-induced basophil activation and identified functional heterogeneity among human IgE molecules: IgE from HRF-responder (HRF-R) basophils derived from $~ 50 \%$ of atopic patients was termed IgE+, and IgE from nonresponders (HRF-NR) was termed IgE- [45]. HRF was also isolated as a B cell growth factor [46], and can stimulate IL-8 secretion from GM-CSF-primed eosinophils [47]. More recently, HRF was shown to stimulate bronchial epithelial cells to produce IL-8 and GM-CSF [48]. Despite intensive efforts, the exact molecular basis of the IgE+/IgE- dichotomy remained an enigma for a number of years. For example, heterogeneity in the carbohydrate portion of $\mathrm{IgE}$ molecules failed to distinguish between IgE+ and IgE- [49]. On the other hand, the releasability of human basophils in response to anti-IgE was correlated positively with Syk tyrosine kinase levels [50-52] and negatively with SHIP (SH2 domain-containing phosphatidylinositol 5' phosphatase) levels [52]. Interestingly, HRF responses in human basophils were shown to negatively correlate with SHIP, but not Syk, levels [53], explaining some HRF-R subjects.

Limited studies on HRF-triggered signaling in human basophils have been performed. The signaling events were found to be identical or similar to those induced by anti-IgE stimulation of human basophils [54] and by antigen stimulation of IgE-sensitized mast cells: 1) stimulation with HRF was not sensitive to pertussis toxin, similar to anti-IgE/IgEinduced basophil activation. 2) Tyrosine phosphorylation of Syk was induced, and a Syk inhibitor blocked HRF-induced histamine release. A recent study also showed that loss of Syk protein was induced in HRF-stimulated human basophils, similar to anti-IgE-stimulated basophils [55]. 3) Increased intracellular $\mathrm{Ca}^{2+}$ and $\mathrm{Ca}^{2+} / \mathrm{MEK}$-dependent leukotriene $\mathrm{C}_{4}$ release $[56,57]$ were induced by HRF in HRF-R, but not HRF-NR, basophils. 4) HRF-induced histamine release was inhibited by the phosphatidylinositol 3-kinase (PI3K) inhibitor LY294002 [53], and phosphorylation of Akt, a PI3K-dependent event, was induced by HRF in HRFR, but not HRF-NR, basophils. 5) MEK and ERK phosphorylation was induced by HRF in HRF-R, but not HRF$\mathrm{NR}$, basophils. Consistent with the many similarities in signaling between HRF-receptor and FceRI, glucocorticoids were shown to inhibit IL-4 production from HRF-stimulated human basophils at the transcriptional level [58]. However, differences were also noted: the Vonakis et al. study [54] found no phosphorylation of FceRI $\gamma(=\mathrm{FcR} \gamma)$ in HRFstimulated basophils. However, this failure may be due to low levels of phosphorylation and limited cell numbers used. A pharmacological study showed that rottlerin, which inhibits protein kinase $C(\mathrm{PKC})-\delta$ and PKC- $\theta$ [59], enhances HRF-mediated histamine release without affecting basophil activation by either anti-IgE or antigen, although staurosporine, Bis II, Gö 6976, or pertussis toxin cannot differentiate histamine release induced by anti-IgE or antigen from that induced by HRF [60].

Most studies on this cytokine-like activity of HRF have been performed with human basophils. Therefore, its exact role in allergic disease has been elusive for two decades. For example, a clinical study failed to find a correlation between bronchial late-phase reactions to Dermatophagoides pteronyssinus (a house dust mite) and IgE reactivity to HRF produced from PBMCs [61]. We believe that these problems stem from three major facts in this research field: 1) the HRF receptor has not been identified, 2) functional validation using animal models of allergic disease has not been attempted, and 3) analysis of the $H R F$ gene has not been performed on a large population of allergic patients. 

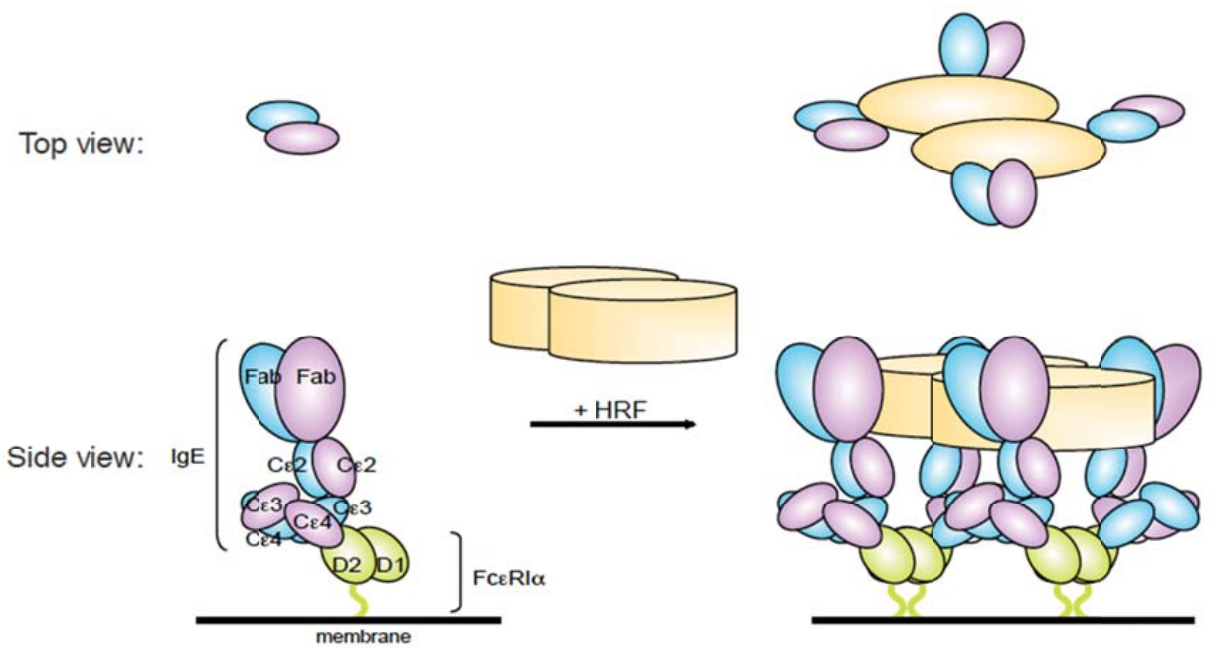

Fig. (2). Model for HRF/IgE-mediated cross-linking of FcERI. IgE binds FceRI $\alpha$ chain via the interaction between Ce3 and D2 domains. HRF can exist as a dimer and one HRF molecule can bind to two molecules of IgE via interactions with the N19 and H3 regions of HRF. The top view (Top) of IgE at the level of Fab and the side view (Bottom) of IgE and IgE-bound FceRI $\alpha$ chain are shown on the left. After binding of an HRF dimer, four FceRI $\alpha$-nucleated complexes will be formed (Right). The cytoplasmic portion of FceRI as well as $\beta$ and $\gamma$ chains of FceRI are omitted for clarity. Taken from ref. 62.

Despite a previous study suggesting that HRF does not interact with $\operatorname{IgE}$, we have recently demonstrated that a subset of IgE antibodies as well as a subset of IgG antibodies bind HRF [62]. HRF can exist as a dimer and bind to the IgE and $\mathrm{IgG}$ (Igs) via interactions of its N-terminal 19-residue and internal $\mathrm{H} 3$ regions with the Fab region of Igs (Fig. 2). Consistent with this, HRF together with HRF-reactive IgE can activate mast cells in vitro and in vivo. Our study showed that the Ig-interacting HRF peptides, N19 and H3, which block HRF-Ig interactions can be used as specific HRF inhibitors that do not interfere with the intracellular functions of TCTP. The inhibitors can inhibit "HRF-reactive IgE"+HRF-induced mast cell activation and in vivo cutaneous anaphylaxis and airway inflammation [62]. Consistent with our data, transgenic mice expressing HRF/TCTP in a lung Clara cell-specific manner exhibit increased macrophages in BAL fluids in naïve mice and increased airway inflammation in OVA-sensitized and OVA-challenged mice [63]. However, the effect of HRF/TCTP overexpression in this transgenic study could not be ascribed solely to the function of the secreted HRF molecule, but the effect of the transgene could be due to the intracellular effect of HRF/TCTP as well. Intranasally administered HRF can recruit inflammatory immune cells to the lung in naïve mice in a mast cell- and Fc receptor-dependent manner [62]. These results indicate that a subset of immunoglobulins are longsought receptors for HRF and strongly suggest that HRF has a proinflammatory role in asthma and skin immediate hypersensitivity.

\section{FUTURE PERSPECTIVES}

As exemplified as above, the search for HRF-interacting molecules has been revealing its functions. We now know a lot about the fundamental roles in cell-cycle progression, proliferation, survival, and malignant transformation. TCTP conventional knockout mice were embryonic lethal [17, 18], thus failed to provide substantial information on its function in in vivo settings. By contrast, conditional knockout mice began to churn out meaningful information: TCTP plays a modest role in thymocyte development, but it is critical for peripheral $\mathrm{T}$ cell maintenance and TCR-mediated cell proliferation [64]. Thus, there might be a chance to find other interacting molecules in $\mathrm{T}$ or other cells. Our recent study demonstrated HRF's proinflammatory role in skin anaphylaxis and airway inflammation [62]. Inhibitors of HRF-Ig interactions are being used to analyze the role of HRF in other models of allergy and other disease models, where $\operatorname{IgE}$ and $\mathrm{IgG}$ play a pathophysiological role. These inhibitors will also be useful to distinguish the roles of HRF's extracellular functions from its intracellular functions in phenomena where only its intracellular functions are assumed.

\section{CONFLICTS OF INTEREST}

None declared.

\section{ACKNOWLEDGEMENT}

None declared.

\section{REFERENCES}

[1] Puig O, Caspary F, Rigaut G, et al. The tandem affinity purification (TAP) method: a general procedure of protein complex purification. Methods [Review] 2001; 24(3): 218-29.

[2] Rigaut G, Shevchenko A, Rutz B, Wilm M, Mann M, Seraphin B. A generic protein purification method for protein complex characterization and proteome exploration. Nat Biotechnol. [Research Support, Non-U.S. Gov't] 1999; 17(10): 1030-2.

[3] Bommer UA, Thiele BJ. The translationally controlled tumour protein (TCTP). Int J Biochem Cell Biol 2004 ;36(3): 379-85.

[4] Hinojosa-Moya J, Xoconostle-Cazares B, Piedra-Ibarra E, MendezTenorio A, Lucas WJ, Ruiz-Medrano R. Phylogenetic and structural analysis of translationally controlled tumor proteins. J Mol Evol 2008; 66(5): 472-83.

[5] Thaw P, Baxter NJ, Hounslow AM, Price C, Waltho JP, Craven CJ. Structure of TCTP reveals unexpected relationship with guanine nucleotide-free chaperones. Nat Struct Biol $2001 ; 8(8): 701-4$.

[6] Vedadi M, Lew J, Artz J, et al. Genome-scale protein expression and structural biology of Plasmodium falciparum and related Apicomplexan organisms. Mol Biochem Parasitol 2007;151(1):100-10. 
[7] Susini L, Besse S, Duflaut D, et al. TCTP protects from apoptotic cell death by antagonizing bax function. Cell Death Differ 2008 ;15(8):1211-20.

[8] Yenofsky R, Cereghini S, Krowczynska A, Brawerman G. Regulation of mRNA utilization in mouse erythroleukemia cells induced to differentiate by exposure to dimethyl sulfoxide. Mol Cell Biol 1983;3(7):1197-203.

[9] Chitpatima ST, Makrides S, Bandyopadhyay R, Brawerman G. Nucleotide sequence of a major messenger RNA for a 21 kilodalton polypeptide that is under translational control in mouse tumor cells. Nucleic Acids Res 1988;16(5):2350.

[10] Thiele H, Berger M, Skalweit A, Thiele BJ. Expression of the gene and processed pseudogenes encoding the human and rabbit translationally controlled tumour protein (TCTP). Eur J Biochem 2000;267(17):5473-81.

[11] Guillaume E, Pineau C, Evrard B, et al. Cellular distribution of translationally controlled tumor protein in rat and human testes. Proteomics 2001;1(7):880-9.

[12] Bommer UA, Borovjagin AV, Greagg MA, et al. The mRNA of the translationally controlled tumor protein P23/TCTP is a highly structured RNA, which activates the dsRNA-dependent protein kinase PKR. RNA 2002;8(4):478-96.

[13] Cans C, Passer BJ, Shalak V, et al. Translationally controlled tumor protein acts as a guanine nucleotide dissociation inhibitor on the translation elongation factor eEF1A. Proc Natl Acad Sci USA 2003; 100(24):13892-7.

[14] Fleischer TC, Weaver CM, McAfee KJ, Jennings JL, Link AJ. Systematic identification and functional screens of uncharacterized proteins associated with eukaryotic ribosomal complexes. Genes Dev 2006; 20(10): 1294-307.

[15] Langdon JM, Vonakis BM, MacDonald SM. Identification of the interaction between the human recombinant histamine releasing factor/translationally controlled tumor protein and elongation factor-1 delta (also known as eElongation factor-1B beta). Biochim Biophys Acta 2004; 1688(3): 232-6.

[16] Hsu YC, Chern JJ, Cai Y, Liu M, Choi KW. Drosophila TCTP is essential for growth and proliferation through regulation of $\mathrm{dRheb}$ GTPase. Nature 2007; 445(7129): 785-8.

[17] Chen $\mathrm{SH}, \mathrm{Wu} \mathrm{PS}$, Chou $\mathrm{CH}$, et al. A knockout mouse approach reveals that TCTP functions as an essential factor for cell proliferation and survival in a tissue- or cell type-specific manner. Mol Biol Cell 2007 ;18(7):2525-32.

[18] Koide Y, Kiyota T, Tonganunt M, et al. Embryonic lethality of fortilin-null mutant mice by BMP-pathway overactivation. Biochim Biophys Acta 2009 ;1790(5):326-38.

[19] Rinnerthaler M, Jarolim S, Heeren G, et al. MMI1 (YKL056c, TMA19), the yeast orthologue of the translationally controlled tumor protein (TCTP) has apoptotic functions and interacts with both microtubules and mitochondria. Biochim Biophys Acta 2006; 1757(5-6): 631-8.

[20] Zhang D, Li F, Weidner D, Mnjoyan ZH, Fujise K. Physical and functional interaction between myeloid cell leukemia 1 protein (MCL1) and Fortilin. The potential role of MCL1 as a fortilin chaperone. J Biol Chem 2002; 277(40): 37430-8.

[21] Liu H, Peng HW, Cheng YS, Yuan HS, Yang-Yen HF. Stabilization and enhancement of the antiapoptotic activity of mcl1 by TCTP. Mol Cell Biol 2005; 25(8): 3117-26.

[22] Yang Y, Yang F, Xiong Z, et al. An N-terminal region of translationally controlled tumor protein is required for its antiapoptotic activity. Oncogene 2005; 24(30): 4778-88.

[23] Tuynder M, Fiucci G, Prieur S, et al. Translationally controlled tumor protein is a target of tumor reversion. Proc Natl Acad Sci U S A 2004; 101(43): 15364-9.

[24] Rho SB, Lee JH, Park MS, et al. Anti-apoptotic protein TCTP controls the stability of the tumor suppressor p53. FEBS Lett 2011; 585(1): 29-35.

[25] Gachet Y, Tournier S, Lee M, Lazaris-Karatzas A, Poulton T, Bommer UA. The growth-related, translationally controlled protein P23 has properties of a tubulin binding protein and associates transiently with microtubules during the cell cycle. J Cell Sci 1999; 112 ( Pt 8): 1257-71.

[26] Yarm FR. Plk phosphorylation regulates the microtubulestabilizing protein TCTP. Mol Cell Biol 2002; 22(17): 6209-21.
[27] Feng Y, Liu D, Yao H, Wang J. Solution structure and mapping of a very weak calcium-binding site of human translationally controlled tumor protein by NMR. Arch Biochem Biophys [Research Support, Non-U.S. Govt] 2007; 467(1): 48-57.

[28] Graidist P, Yazawa M, Tonganunt M, et al. Fortilin binds $\mathrm{Ca} 2+$ and blocks Ca2+-dependent apoptosis in vivo. Biochem J [Comparative Study Research Support, N.I.H., Extramural RESEARCH Support, Non-U.S. Gov't Validation Studies] 2007 ;408(2):181-91.

[29] Kim M, Jung Y, Lee K, Kim C. Identification of the calcium binding sites in translationally controlled tumor protein. Arch Pharm Res 2000; 23(6): 633-6.

[30] Sanchez JC, Schaller D, Ravier F, et al. Translationally controlled tumor protein: a protein identified in several nontumoral cells including erythrocytes. Electrophoresis [Research Support, NonU.S. Gov't] 1997;18(1): 150-5.

[31] Jung J, Kim M, Kim MJ, et al. Translationally controlled tumor protein interacts with the third cytoplasmic domain of $\mathrm{Na}, \mathrm{K}$ ATPase alpha subunit and inhibits the pump activity in HeLa cells. J Biol Chem [Research Support, Non-U.S. Gov't] 2004; 279(48): 49868-75.

[32] Fenner BJ, Scannell M, Prehn JH. Expanding the substantial interactome of NEMO using protein microarrays. PLoS One 2010; 5(1): e8799.

[33] Rid R, Onder K, Trost A, et al. H2O2-dependent translocation of TCTP into the nucleus enables its interaction with VDR in human keratinocytes: TCTP as a further module in calcitriol signalling. J Steroid Biochem Mol Biol 2010; 118(1-2): 29-40.

[34] Yoon T, Jung J, Kim M, Lee KM, Choi EC, Lee K. Identification of the self-interaction of rat TCTP/IgE-dependent histaminereleasing factor using yeast two-hybrid system. Arch Biochem Biophys 2000; 384(2): 379-82.

[35] Thueson DO, Speck LS, Lett-Brown MA, Grant JA. Histaminereleasing activity (HRA). I. Production by mitogen- or antigenstimulated human mononuclear cells. J Immunol 1979; 123(2): 626-32.

[36] MacDonald SM. HIstamine releasing factors. In: Razin E, Rivera J, Eds. Signal transduction in mast cells and basophils. New York: Springer-Verlag 1999; pp. 390-401.

[37] MacDonald SM, Rafnar T, Langdon J, Lichtenstein LM. Molecular identification of an IgE-dependent histamine-releasing factor. Science 1995;269(5224):688-90.

[38] Warner JA, Pienkowski MM, Plaut M, Norman PS, Lichtenstein LM. Identification of histamine releasing factor(s) in the late phase of cutaneous IgE-mediated reactions. J Immunol 1986; 136(7): 2583-7.

[39] MacDonald SM, Lichtenstein LM, Proud D, et al. Studies of IgEdependent histamine releasing factors: heterogeneity of $\operatorname{IgE}$. J Immunol 1987; 139(2): 506-12.

[40] MacDonald SM. Histamine releasing factors and $\operatorname{IgE}$ heterogeneity. In: Middleton E, Reed CE, Ellis EF, Adkinson NF, Yunginger JW, Busse WW, Eds. Principles and practice. $4^{\text {th }}$ ed. St Louis: Mosby-Year Book Incorporated 1993.

[41] Sampson HA, Broadbent KR, Bernhisel-Broadbent J. Spontaneous release of histamine from basophils and histamine-releasing factor in patients with atopic dermatitis and food hypersensitivity. $\mathrm{N} \mathrm{Engl}$ J Med 1989; 321(4): 228-32.

[42] Amzallag N, Passer BJ, Allanic D, et al. TSAP6 facilitates the secretion of translationally controlled tumor protein/histaminereleasing factor via a nonclassical pathway. J Biol Chem 2004; 279(44): 46104-12.

[43] Schroeder JT, Lichtenstein LM, MacDonald SM. An immunoglobulin E-dependent recombinant histamine-releasing factor induces interleukin-4 secretion from human basophils. J Exp Med 1996; 183(3): 1265-70.

[44] Schroeder JT, Lichtenstein LM, MacDonald SM. Recombinant histamine-releasing factor enhances IgE-dependent IL-4 and IL-13 secretion by human basophils. J Immunol 1997; 159(1): 447-52.

[45] MacDonald SM. Human recombinant histamine-releasing factor. Int Arch Allergy Immunol 1997; 113(1-3): 187-9.

[46] Kang HS, Lee MJ, Song H, et al. Molecular identification of IgEdependent histamine-releasing factor as a B cell growth factor. J Immunol 2001; 166(11): 6545-54.

[47] Bheekha-Escura R, MacGlashan DW, Langdon JM, MacDonald SM. Human recombinant histamine-releasing factor activates 
human eosinophils and the eosinophilic cell line, AML14-3D10. Blood $2000 ; 96(6): 2191-8$.

[48] Yoneda K, Rokutan K, Nakamura Y, Yanagawa H, KondoTeshima S, Sone S. Stimulation of human bronchial epithelial cells by IgE-dependent histamine-releasing factor. Am J Physiol Lung Cell Mol Physiol 2004 ;286(1):L174-81.

[49] Kleine-Tebbe J, Kagey-Sobotka A, MacGlashan DW Jr., Lichtenstein LM, MacDonald SM. Lectins do not distinguish between heterogenous IgE molecules as defined by differential activity of an IgE-dependent histamine releasing factor. J Allergy Clin Immunol 1996;98(1):181-8.

[50] Kepley CL, Youssef L, Andrews RP, Wilson BS, Oliver JM. Syk deficiency in nonreleaser basophils. J Allergy Clin Immunol 1999; ;104(2 Pt 1):279-84.

[51] Lavens-Phillips SE, MacGlashan DW Jr. The tyrosine kinases p53/56lyn and p72syk are differentially expressed at the protein level but not at the messenger RNA level in nonreleasing human basophils. Am J Respir Cell Mol Biol 2000 ;23(4):566-71.

[52] MacGlashan DW Jr. Relationship between spleen tyrosine kinase and phosphatidylinositol 5' phosphatase expression and secretion from human basophils in the general population. J Allergy Clin Immunol 2007;119(3):626-33.

[53] Vonakis BM, Gibbons S, Jr., Sora R, Langdon JM, MacDonald SM. Src homology 2 domain-containing inositol 5' phosphatase is negatively associated with histamine release to human recombinant histamine-releasing factor in human basophils. J Allergy Clin Immunol 2001;108(5):822-31.

[54] Vonakis BM, Macglashan DW Jr., Vilarino N, Langdon JM, Scott RS, MacDonald SM. Distinct characteristics of signal transduction events by histamine-releasing factor/translationally controlled tumor protein (HRF/TCTP)-induced priming and activation of human basophils. Blood 2008;111(4):1789-96.

[55] MacGlashan DW Jr., Ishmael S, MacDonald SM, Langdon JM, Arm JP, Sloane DE. Induced loss of Syk in human basophils by non-IgE-dependent stimuli. J Immunol 2008;180(6):4208-17.
[56] MacGlashan DW Jr., Hubbard WC. IL-3 alters free arachidonic acid generation in C5a-stimulated human basophils. J Immunol 1993;151(11):6358-69.

[57] Miura K, Schroeder JT, Hubbard WC, MacGlashan DW Jr. Extracellular signal-regulated kinases regulate leukotriene $\mathrm{C} 4$ generation, but not histamine release or IL-4 production from human basophils. J Immunol 1999 1;162(7):4198-206.

[58] Schroeder JT, MacGlashan DW Jr, MacDonald SM, KageySobotka A, Lichtenstein LM. Regulation of IgE-dependent IL-4 generation by human basophils treated with glucocorticoids. J Immunol 1997 1;158(11):5448-54.

[59] Coudronniere N, Villalba M, Englund N, Altman A. NF-kappa B activation induced by $\mathrm{T}$ cell receptor/CD28 costimulation is mediated by protein kinase C-theta. Proc Natl Acad Sci USA 2000; 97(7): 3394-9.

[60] Bheekha-Escura R, Chance SR, Langdon JM, MacGlashan DW Jr., MacDonald SM. Pharmacologic regulation of histamine release by the human recombinant histamine-releasing factor. J Allergy Clin Immunol 1999;103(5 Pt 1):937-43.

[61] Budde IK, Lopuhaa CE, de Heer PG, et al. Lack of correlation between bronchial late allergic reaction to Dermatophagoides pteronyssinus and in vitro immunoglobulin $\mathrm{E}$ reactivity to histamine-releasing factor derived from mononuclear cells. Ann Allergy Asthma Immunol 2002; 89(6): 606-12.

[62] Kashiwakura JI, Ando T, Matsumoto K, et al. Histamine-releasing factor has a proinflammatory role in mouse models of asthma and allergy. J Clin Investig 2012; 122(1):218-28.

[63] Yeh YC, Xie L, Langdon JM, et al. The effects of overexpression of histamine releasing factor (HRF) in a transgenic mouse model. PLoS One 2010; 5(6): e11077.

[64] Wu PS, Yang CY, Yen JJ, et al. Critical roles of translationally controlled tumor protein in the homeostasis and TCR-mediated proliferation of peripheral T cells. J Immunol [Research Support, Non-U.S. Gov't] 2009 15; 183(4):2373-81.

Received: January 25, 2012

(C) Kawakami et al.; Licensee Bentham Open.

This is an open access article licensed under the terms of the Creative Commons Attribution Non-Commercial License (http://creativecommons.org/licenses/by-nc/3.0/) which permits unrestricted, non-commercial use, distribution and reproduction in any medium, provided the work is properly cited. 